\title{
Polyphenol mixtures of Euphorbia supina the inhibit invasion and metastasis of highly metastatic breast cancer MDA-MB-231 cells
}

\author{
YOUNG SHIN KO ${ }^{1}$, WON SUP LEE ${ }^{2}$, YOUNG NAK JOO ${ }^{1}$, YUNG HYUN CHOI ${ }^{4}$, GON SUP KIM ${ }^{5}$, \\ JIN-MYUNG JUNG ${ }^{3}$, CHUNG HO RYU ${ }^{7}$, SUNG CHUL SHIN ${ }^{6}$ and HYE JUNG KIM ${ }^{1}$
}

\begin{abstract}
Departments of ${ }^{1}$ Pharmacology, ${ }^{2}$ Internal Medicine and ${ }^{3}$ Neurosurgery, School of Medicine, Institute of Health Sciences, Gyeongsang National University, Jinju 660-702; ${ }^{4}$ Department of Biochemistry, College of Oriental Medicine, Dongeui University and Department of Biomaterial Control (BK21 Program), Dongeui University Graduate School, Busan 614-052; ${ }^{5}$ School of Veterinary Medicine and ${ }^{6}$ Department of Chemistry, Research Institute of Life Science, Gyeongsang National University, Jinju 660-701; ${ }^{7}$ Division of Applied Life Science (BK21 Program), Institute of Agriculture and Life Science, Gyeongsang National University, Jinju 660-701, Republic of Korea
\end{abstract}

Received June 22, 2015; Accepted August 24, 2015

DOI: $10.3892 / o r .2015 .4304$

\begin{abstract}
The Korean prostrate spurge Euphorbia supina is abundant in polyphenols and has been used as a folk medicine in Korea against a variety of diseases. Thus, we aimed to investigate the effect of polyphenol mixtures of Korean Euphorbia supina (PES) on the invasion and metastasis of highly metastatic breast cancer MDA-MB-231 cells. Firstly, PES showed no cytotoxicity on cancer cells and endothelial cells (ECs) at the doses of $0.1-10 \mu \mathrm{g} / \mathrm{ml}$, but showed significant cytotoxicity from $50 \mu \mathrm{g} / \mathrm{ml}$. Thus, we performed subsequent experiments with PES at doses up to $5 \mu \mathrm{g} / \mathrm{ml}$. PES dose-dependently suppressed epithelial-mesenchymal transition by downregulating the mesenchymal markers, Snaill and N-cadherin, showing significant inhibition from 1 and $5 \mu \mathrm{g} / \mathrm{ml}$, respectively. In addition,
\end{abstract}

Correspondence to: Professor Hye Jung Kim, Department of Pharmacology, School of Medicine, Institute of Health Sciences, Gyeongsang National University, Jinju 660-702, Republic of Korea E-mail: hyejungkim@gnu.ac.kr

Professor Won Sup Lee, Department of Internal Medicine, School of Medicine, Institute of Health Sciences, Gyeongsang National University, Jinju 660-702, Republic of Korea

E-mail: lwshmo@hanmail.net; lwshmo@gnu.ac.kr

Abbreviations: AJs, adherens junctions; CAM, cell adhesion molecule; CM, conditioned media; DAPI, 4',6-diamino-2phenylindole; ECs, endothelial cells; ECM, extracellular matrix; ECL, enhanced chemiluminescence; EMT, epithelial-mesenchymal transition; FBS, fetal bovine serum; ICAM, intracellular adhesion molecule; LOX, lysyl oxidase; MTT, 3-[4,5-dimethylthiazol-2-yl]2,5-diphenyltetrazolium bromide; PBS, phosphate-buffered saline; SDS, sodium dodecyl surfate; TBS, Tris-buffered saline; TNF, tumor necrosis factor; VCAM, vascular cell adhesion molecule; VE-cadherin, vascular endothelial cadgerin

Key words: breast cancer cells, endothelial cells, metastasis, Euphorbia supina, VCAM-1, epithelial-mesenchymal transition
PES significantly inhibited MMP-9 activity and LOX release induced by TNF- $\alpha$ at $5 \mu \mathrm{g} / \mathrm{ml}$. Then, we determined the effect of PES on the expression of adhesion molecules and VE-cadherin phosphorylation. The results showed that PES effectively reduced TNF- $\alpha$-mediated VCAM-1 expression but not ICAM expression both in the MDA-MB-231 cells and ECs, resulting in the reduced adhesion of MDA-MB-231 to ECs. Finally, PES effectively inhibited MDA-MB-231 cell invasion through ECs, suggesting that PES may serve as a therapeutic agent against cancer metastasis with minimal cytotoxicity to normal cells.

\section{Introduction}

Natural compounds exhibit a wide range of anticancer effects, including cell cycle arrest, apoptosis, anti-angiogenesis, and anticancer invasion and migration. Natural phytochemicals containing phenolic compounds have been widely documented to have the capability to prevent cancer metastasis (1). The Korean prostrate spurge Euphorbia supina is a weed that belongs to the Euphorbiaceae family. The plant has been used in folk medicine in Korea against a variety of conditions such as bronchitis, jaundice, hemorrhage and gastrointestinal diseases including gastritis, peptic ulcer, diarrhea and hemorrhoid $(2,3)$. It has been reported that this plant contains a number of biologically important organic substances (4-6). Among these, polyphenols have attracted a great deal of interest due to their beneficial effects on human health. Epidemiological studies have shown that polyphenols reduce the risk of chronic diseases $(7,8)$, and have anti-oxidant, anti-aging, and anti-microbial properties (9). According to Song et al (10), nine polyphenols have been isolated and identified from Korean E. supine, and quercetin and kaempferol derivatives account for $84.8 \%$ of the total polyphenols. Therefore, the inhibitory effects of E. supine on cancer growth and metastasis could be expected; however, few studies have been performed to demonstrate this effect.

Breast cancer is the most common cancer diagnosed in Western European and North American women. Asian 
populations are generally at the lowest risk, but the incidence has been steadily increasing. Particularly, in Korea, the incidence of breast cancer has increased by more than four times from 1996 to 2010, showing the highest growth of breast cancer in the OECD countries (11). Most breast cancer patients virtually die of metastasis. Cancer metastasis is the spread of cancer cells from the primary neoplasm to distant sites, where secondary tumors are formed. Its process involves several steps: the entrance of cancer cells from the primary tumor into the vasculature, migration to distant organs, adhesion to endothelial cells lining the blood vessels, extravasation from the blood vessels, and the final proliferation of secondary tumors (12). Thus, to enhance the survival of cancer patients as well as the quality of life, the blockade of the metastatic cascade with natural compounds has gained research interest. In the present study, we investigated the effects of polyphenol mixtures of Korean Euphorbia supina on the invasion and metastasis of highly metastatic breast cancer MDA-MB-231 cells.

\section{Materials and methods}

Preparation of polyphenol mixtures of Euphorbia supine (E. supine). Polyphenols from E. supine (PES) were extracted and purified by Professor S.C. Shin as reported in Song et al (10). Briefly, the lyophilized E. supine tissue $(10 \mathrm{~g})$ was ground into powder and extracted in ethyl acetate $(300 \mathrm{ml})$ at $80^{\circ} \mathrm{C}$ for $20 \mathrm{~h}$, and eluted using a mixture of methanol:dichloromethane $(1: 5,25 \mathrm{ml})$. The isolated polyphenol mixtures were identified by HPLC-MS/MS according to a previous method (13). The nine polyphenols in the Korean E. supina were as follows: gallic acid, protocatechuic acid, nodakenin, quercetin-3- $O$-hexoside, quercetin-3- $O$-pentoside, kaempferol 3- $O$-hexoside, kaempferol 3- $O$-pentoside, quercetin and kaempferol. Quercetin and kaempferol derivatives formed $84.8 \%$ of the total polyphenols (10).

Materials. Anti-VCAM-1, anti-ICAM-1, anti-Snail, anti-N-cadherin, anti- $\beta$-catenin, anti-E-cadherin, anti-VE-cadherin and anti-LOX antibodies were purchased from Santa Cruz Biotechnology (Santa Cruz, CA, USA). Anti-phospho-VE-cadherin (phospho-Y658) antibody was purchased from Abcam (Cambridge, MA, USA). Matrigel ${ }^{\mathrm{TM}}$ basement membrane matrix was supplied by BD Biosciences (San Diego, CA, USA). Enhanced chemiluminescence (ECL) western blotting detection reagent was obtained from Amersham (Buckinghamshire, UK). All other chemicals, including $\beta$-actin, were purchased from Sigma-Aldrich (St. Louis, MO, USA).

Cell culture. Human breast cancer cell line, MDA-MB-231, was obtained from the Korean Cell Line Bank (Seoul, Korea) and grown in RPMI-1640 supplemented with $10 \%$ fetal bovine serum (FBS), $2 \mathrm{mM}$ L-glutamine, $25 \mathrm{mM}$ $N$-2-hydroxyethylpiperazine- $N$ '-2-ethanesulfonic acid, $25 \mathrm{mM}$ $\mathrm{NaHCO}_{3}, 100 \mathrm{IU} / \mathrm{ml}$ penicillin and $10 \mu \mathrm{g} / \mathrm{ml}$ streptomycin. Human umbilical vein endothelial cell line (EA.hy 926 cell) was obtained from the American Type Culture Collection (ATCC) and grown in medium 199 supplemented with $20 \%$ FBS, $2 \mathrm{mM}$ L-glutamine, $5 \mathrm{U} / \mathrm{ml}$ heparin, $100 \mathrm{IU} / \mathrm{ml}$ penicillin,
$10 \mu \mathrm{g} / \mathrm{ml}$ streptomycin and $50 \mu \mathrm{g} / \mathrm{ml}$ EC growth supplements. Cells were cultured in $100-\mathrm{mm}$ dishes at $37^{\circ} \mathrm{C}$ in a humidified atmosphere of $95 \%$ air and $5 \% \mathrm{CO}_{2}$.

Cell viability assay. Cells were seeded at $10^{4}$ cells/well in 24-well plates. Cells were treated with PES at the indicated doses for $24 \mathrm{~h}$. After treatments, $50 \mu \mathrm{l}$ of $5 \mathrm{mg} / \mathrm{ml}$ MTT solution was added to each well and incubated for $4 \mathrm{~h}$. The supernatants were aspirated, and the formazan crystals were dissolved with $200 \mu \mathrm{l}$ of $4 \mathrm{~N} \mathrm{HCl}$-isopropanol in each well. The optical density of the colored product was measured at $570 \mathrm{~nm}$, as suggested by the manufacturer, using an Infinite 200 microplate reader (Tecan Austria GmbH, Grödig, Austria).

Western blot analysis. Western blot analysis was performed as described previously (14), with minor modifications. Briefly, cells were lysed using PRO-PREP protein extraction solution (iNtRON Biotechnology, Seoul, Korea), and proteins in conditioned media (CM) were concentrated 20-fold with Pierce concentrator $7 \mathrm{ml} / 9 \mathrm{~K}$, MWCO devices (Thermo Pierce, Rockford, IL, USA). The protein concentration was determined by the Bradford method. Aliquots of $50 \mu \mathrm{g}$ of protein were subjected to $7.5-12.5 \%$ sodium dodecyl sulfate-polyacrylamide gel electrophoresis (SDS-PAGE) and transferred onto Hybond- $\mathrm{P}^{+}$polyvinylidene difluoride membranes (Amersham Biosciences UK Ltd.). The membranes were incubated with the indicated primary antibodies. The bound antibodies were detected with horseradish peroxidase-conjugated secondary antibodies and an ECL western blotting detection reagent (Bionote, Gyeonggi-do, Korea). $\beta$-actin was used as a loading control.

Adhesion assay. ECs and MDA-MB-231 cells were treated with PES for $24 \mathrm{~h}$ and subsequently stimulated with TNF- $\alpha$ for $6 \mathrm{~h}$. Thereafter, MDA-MB-231 cells $\left(7.5 \times 10^{5}\right.$ cells $\left./ \mathrm{ml}\right)$ were added to the ECs. After $30 \mathrm{~min}$ at $37^{\circ} \mathrm{C}$, cell suspensions were withdrawn, and the ECs were gently washed with PBS three times. The cells were then counted under a light microscope, and images were taken using an Olympus microscope (CKX41) equipped with a camera (DS-U3; Nikon).

Matrigel invasion assay. The Matrigel invasion assays were performed using EC coated-Matrigel. ECs were pretreated with PES for $24 \mathrm{~h}$ and then washed with PBS three times. After ECs were stimulated with TNF- $\alpha$ for $6 \mathrm{~h}$, MDA-MB-231 cells were added to EC-Matrigel-coated wells and incubated for $24 \mathrm{~h}$. The non-invasive cells that remained on the upper side of the insert were removed. The cells on the lower part of the insert membranes were stained with 4',6-diamino-2-phenylindole (DAPI) and counted under a light microscope.

Gelatin zymography. Media were prepared from MDA-MB-231 cells and concentrated 20 -fold using protein concentrators $(9 \mathrm{~K}$ MWCO). Proteins in the media were precipitated with $80 \%$ cold acetone. Precipitated proteins were mixed with sample buffer $(0.03 \%$ bromophenol blue, $0.4 \mathrm{M}$ Tris- $\mathrm{HCl} \mathrm{pH} 7.4,20 \%$ glycerol, 5\% SDS) and separated on $8 \%$ SDS-polyacrylamide gels containing gelatin $(1 \mathrm{mg} / \mathrm{ml})$. Thereafter, the gels were washed with renaturing buffer $(2.5 \%$ Triton $\mathrm{X}-100)$ for $1 \mathrm{~h}$ and subsequently incubated for $24 \mathrm{~h}$ at $37^{\circ} \mathrm{C}$ in developing 
A

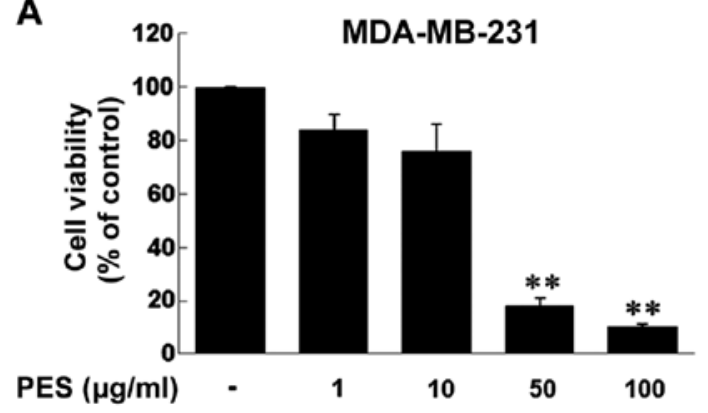

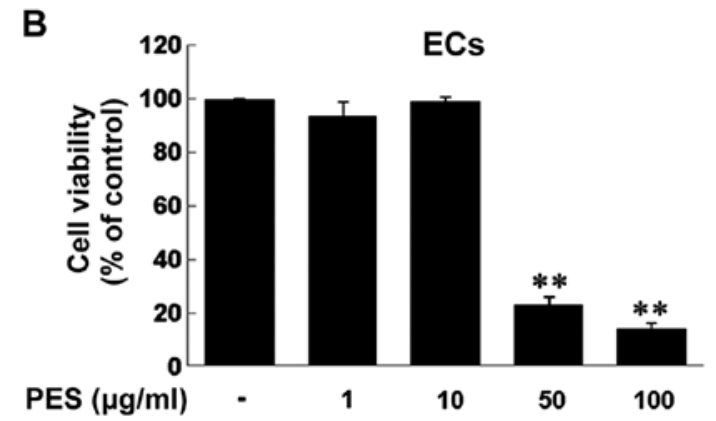

Figure 1. Effect of PES on the cell viability of breast cancer MDA-MB-231 cells (A) or EA.hy 926 HUVECs (B). MDA-MB-231 and EA.hy 926 cells were starved for $16 \mathrm{~h}$ and then treated with the indicated concentrations of PES. After $24 \mathrm{~h}$, cell viability was determined by MTT assay. Values are the means \pm SEM from three independent determinations. ${ }^{* *} \mathrm{P}<0.01$ compared with the vehicle-treated group.

buffer (50 mM Tris, $20 \mathrm{mM} \mathrm{NaCl,} 5 \mathrm{mM} \mathrm{CaCl}_{2}, 0.02 \%$ Brij35, $\mathrm{pH}$ 7.5). Gels were stained with $0.05 \%$ Coomassie Brilliant Blue R-250 and destained with $50 \%$ methanol and $10 \%$ acetic acid. Within the blue background, clear zones indicated MMP proteolytic activity.

Statistical analysis. Scanning densitometry was performed using Image Master ${ }^{\circledR}$ VDS (Pharmacia Biotech Inc., San Francisco, CA, USA). The treatment groups were compared using one-way analysis of variance and the post hoc test by Scheffe. All data are expressed as the mean \pm standard error of the mean (SEM). $\mathrm{P}<0.05$ was considered to indicate a statistically significant result.

\section{Results}

Effect of PES on the cell viability of MDA-MB-231 breast cancer cells and ECs. First, we examined the cell viability of MDA-MB-231 breast cancer cells and ECs in response to PES treatment in a dose-dependent manner $(1,10,50$ and $100 \mu \mathrm{g} /$ ml). When MDA-MB-231 cells and ECs were treated with the indicated doses of PES for $24 \mathrm{~h}$, the results revealed that the doses of 1 and $10 \mu \mathrm{g} / \mathrm{ml}$ of PES did not decrease the cell viability of both MDA-MB-231 cells and ECs, but the doses of 50 and $100 \mu \mathrm{g} / \mathrm{ml}$ significantly decreased the cell viability of both types of cells (Fig. 1).

PES downregulates the levels of mesenchymal markers and inhibits MMPs and lysyl oxidase (LOX) secretion in TNF- $\alpha$-treated MDA-MB-231 cells. Next, we observed changes in MDA-MB-231 cell morphology after PES treatment. Fig. 2A showed that PES induced morphologic changes in the MDA-MB-231 cells from a mesenchymal form to an epithelial form in a dose-dependent manner. Furthermore, PES significantly reduced the levels of mesenchymal markers Snail and $\mathrm{N}$-cadherin at the dose of 1 or $5 \mu \mathrm{g} / \mathrm{ml}$, but not $\beta$-catenin and E-cadherin levels (data not shown). These results suggest that PES suppresses EMT by downregulating the mesenchymal markers, Snaill and N-cadherin (Fig. 2B). Proteolytic digestion of the extracellular matrix (ECM) by secreted MMPs is one of the major steps for cancer invasion (reviewed in refs. 15 and 16), and MMP-9 expression is involved in tumor-cell invasion and metastasis (17). In addition, LOX is overexpressed in breast cancer patients and is known to be a novel mecha- nism for the promotion of metastasis (18). Thus, we examined the effect of PES on the activity of secreted MMP-9 and the level of LOX in MDA-MB-231 cells in the presence of TNF- $\alpha$ or not. PES suppressed the gelatinolytic activity of secreted MMP-9 augmented by TNF- $\alpha$ in the MDA-MB-231 cells; the suppressive effect was significant at $5 \mu \mathrm{g} / \mathrm{ml}$ of PES (Fig. 2C). Fig. 2D showed that induction in LOX secretion by TNF- $\alpha$ was also prominently reduced at $5 \mu \mathrm{g} / \mathrm{ml}$ of PES.

PES reduces the expression of VCAM-1 induced by TNF- $\alpha$ in MDA-MB-231 cells and ECs, and inhibits the adhesion of MDA-MB-231 cells to TNF- $\alpha$-stimulated ECs. The adhesion of circulating tumor cells to the microvascular endothelium of distant organs is an important step in blood-born metastasis. ICAM-1 and VCAM-1 have been shown to be involved in cell-cell and cell-ECM interactions and are mechanistically important for the extravasation of both monocytes and cancer cells (19-21) during inflammation and metastasis, respectively. Therefore, we examined whether PES inhibits VCAM-1 and ICAM-1 expression induced by TNF- $\alpha$ in ECs as well as in MDA-MB-231 cells. Pretreatment of PES significantly inhibited TNF- $\alpha$-induced VCAM-1 expression, but not ICAM-1 expression in both the MDA-MB-231 cells and ECs (Fig. 3). Then, we investigated the effect of PES on the adhesion of MDA-MB-231 cells to ECs. The adhesion of the MDA-MB-231 cells to ECs was markedly increased by TNF- $\alpha$ treatment $(10 \mathrm{ng} / \mathrm{ml}, 6 \mathrm{~h})$, compared to unactivated ECs. In contrast, the treatment of PES $(0.1-5 \mu \mathrm{g} / \mathrm{ml})$ to ECs for $1 \mathrm{~h}$ before TNF- $\alpha$ stimulation resulted in a significant reduction in the adhesion of the MDA-MB-231 cells to ECs (Fig. 4).

PES inhibits the phosphorylation of VE-cadherin mediated by TNF- $\alpha$ in ECs. Tyrosine phosphorylation of VE-cadherin is known to be associated with weak junctions and impaired barrier function. Therefore, we investigated the effect of PES on the phosphorylation of VE-cadherin at tyrosine residue 658 (Y658) by western blotting. PES treatment $1 \mathrm{~h}$ prior to TNF- $\alpha$ decreased TNF- $\alpha$-induced phospho-VE-cadherin from $1 \mu \mathrm{g} /$ $\mathrm{ml}$ of PES, showing a significant inhibition at $5 \mu \mathrm{g} / \mathrm{ml}$ (Fig. 5).

PES downregulates MDA-MB-231 cell invasion induced by $T N F-\alpha$. Finally, we examined the effect of PES on MDA-MB-231 cell invasion through ECs. ECs were pretreated with PES for $1 \mathrm{~h}$ and stimulated with TNF- $\alpha$ for an 
A

MDA-MB-231
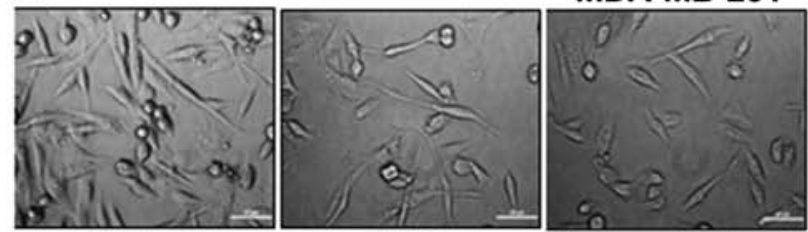

Control

TNF- $\alpha$

TNF- $\alpha+$ PES 0.1

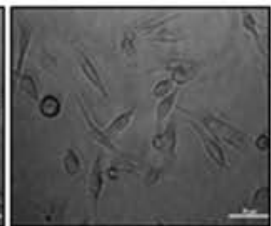

TNF- $\alpha+$ PES 1

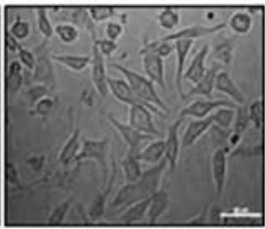

TNF- $\alpha+$ PES 5
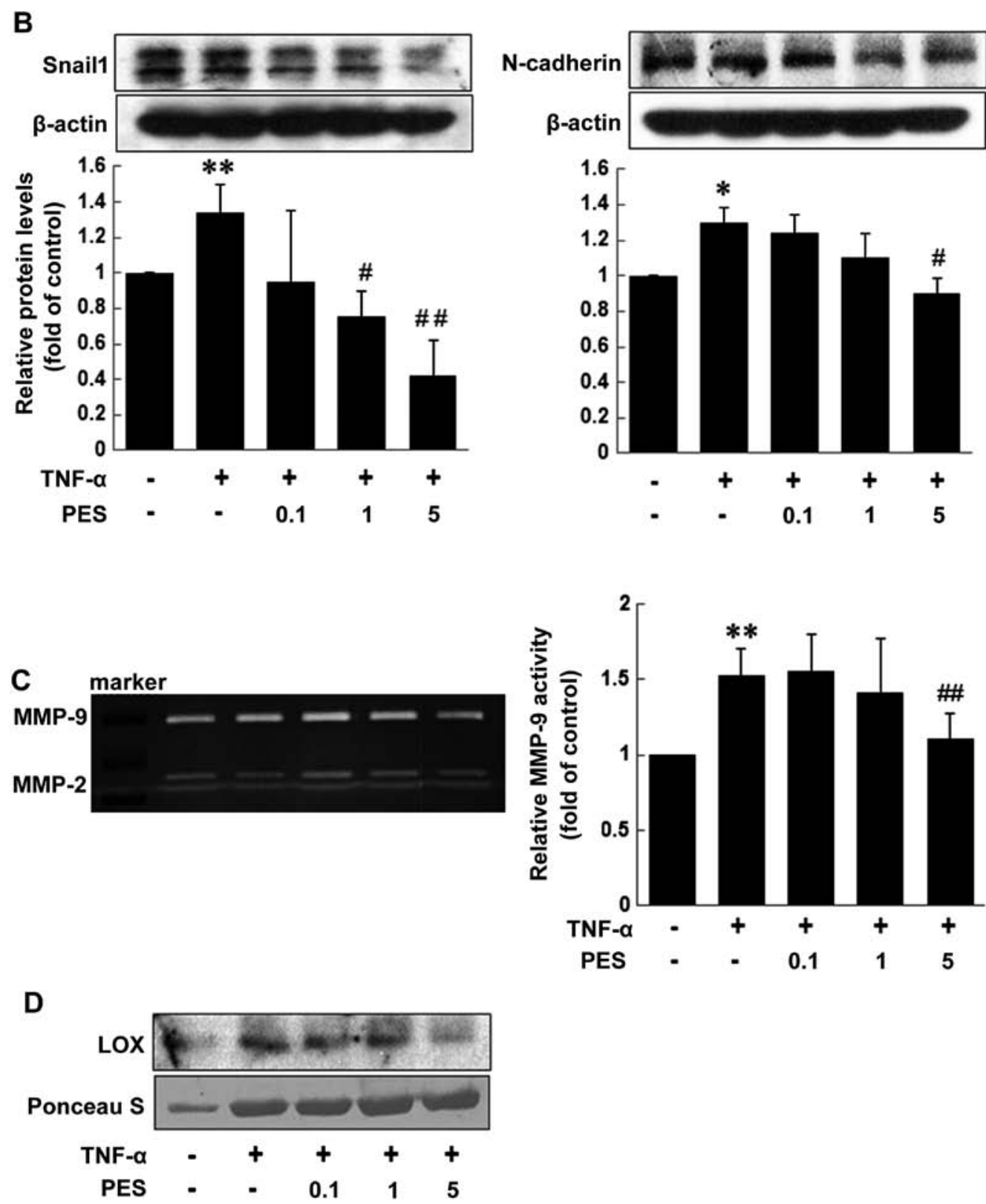

Figure 2. PES downregulates the levels of mesenchymal markers and MMP-9 and LOX secretion in MDA-MB-231 cells. (A) Cells were seeded at $5 \times 10^{4} \mathrm{cells} / \mathrm{ml}$ and pretreated with PES $(0.1,1$ or $5 \mu \mathrm{g} / \mathrm{ml})$ for $1 \mathrm{~h}$. The cells were then treated with TNF- $\alpha(10 \mathrm{ng} / \mathrm{ml})$ for an additional $6 \mathrm{~h}$, and the morphologic changes in the cells were observed under a microscope (x400 magnification). Data are representative of three independent experiments. (B-D) MDA-MB-231 cells were treated with PES and TNF- $\alpha$ as described in A. (B) The levels of Snaill and N-cadherin in the cell lysates were determined by western blot analysis. (C) MMP gelatinase activity was measured in CM as described in Materials and methods. Data are presented as the mean values \pm SEM of three independent experiments. ${ }^{*} \mathrm{P}<0.05$; ${ }^{* *} \mathrm{P}<0.01$ compared with the control group; ${ }^{*} \mathrm{P}<0.05$, ${ }^{\# \#} \mathrm{P}<0.01$ compared with TNF- $\alpha$-treated group. (D) LOX levels secreted from the cells were analyzed by western blot analysis. Results were confirmed by repeated experiments.

additional $6 \mathrm{~h}$. Then, MDA-MB-231 cells were added to the EC-Matrigel-coated wells and incubated for $24 \mathrm{~h}$. As shown in Fig. 6, PES dose-dependently inhibited MDA-MB-231 cell invasion through TNF- $\alpha$-stimulated ECs. 
A

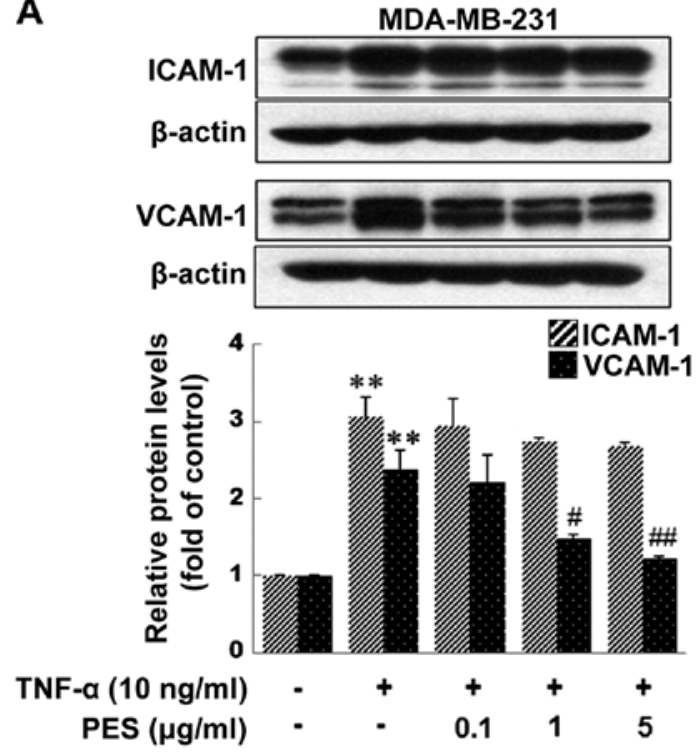

B

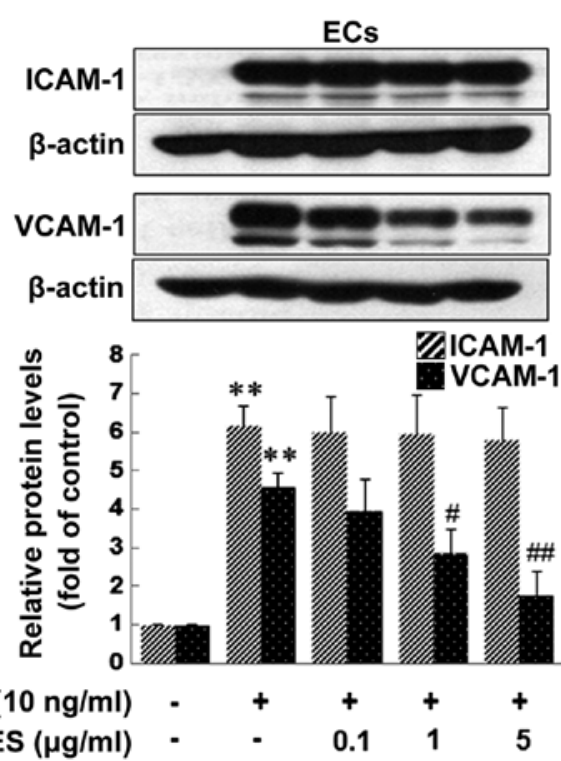

Figure 3. PES reduces the expression of VCAM-1 induced by TNF- $\alpha$ in MDA-MB-231 and EA.hy 926 cells. (A) MDA-MB-231 and (B) EA.hy 926 cells were pretreated with PES at $0.1,1$ or $5 \mu \mathrm{g} / \mathrm{ml}$ for $1 \mathrm{~h}$, and then stimulated with TNF- $\alpha(10 \mathrm{ng} / \mathrm{ml})$ for $6 \mathrm{~h}$. After treatments, the proteins were extracted from the cells, and ICAM-1, VCAM-1 and $\beta$-actin protein levels were determined by western blot analysis and quantified. Values are the means \pm SEM from three independent determinations. ${ }^{* *} \mathrm{P}<0.01$ compared with the control group; ${ }^{~} \mathrm{P}<0.05,{ }^{\# \#} \mathrm{P}<0.01$ compared with the TNF- $\alpha$-treated group.

A
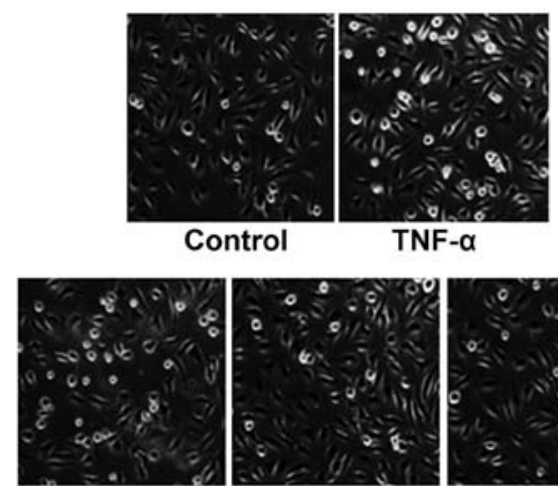

Control
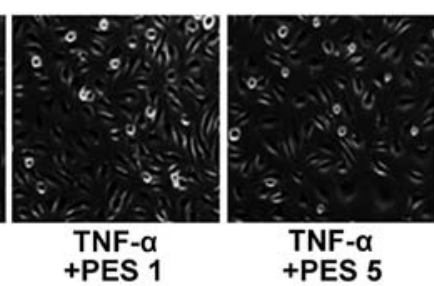

B +PES 0.1

+ PES

+PES 5

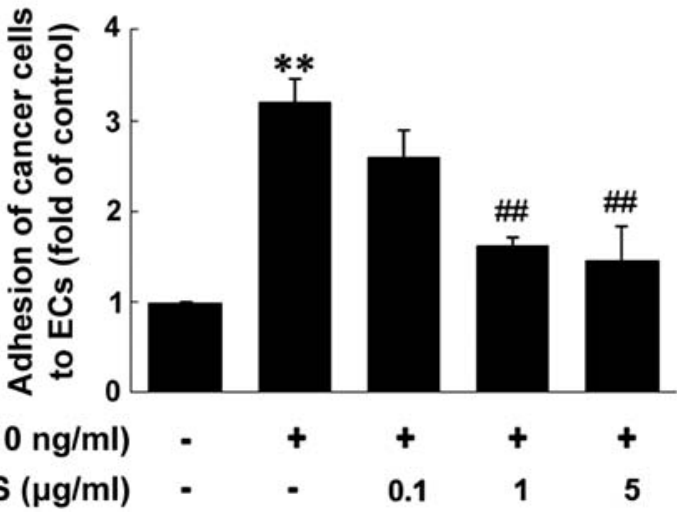

Figure 4. PES inhibits TNF- $\alpha$-mediated adhesion of breast cancer cells to ECs. EA.hy 926 cells were pretreated with PES at $0.1,1$ or $5 \mu \mathrm{g} / \mathrm{ml}$ for $1 \mathrm{~h}$, and cells were then stimulated with TNF- $\alpha(10 \mathrm{ng} / \mathrm{ml})$ for $6 \mathrm{~h}$. EA.hy 926 cells were washed with serum-free medium, and MDA-MB-231 cells were added onto EA.hy 926 cells and incubated for $30 \mathrm{~min}$ at $37^{\circ} \mathrm{C}$. Cells were gently washed, and adherent MDA-MB-231 cells to EA.hy 926 cells were (A) observed under light microscope and (B) quantified. Values are the means \pm SEM from three independent determinations. ${ }^{* *} \mathrm{P}<0.01$ compared with the control group; ${ }^{\# \#} \mathrm{P}<0.01$ compared with the TNF- $\alpha$-treated group.

\section{Discussion}

Great advances in medical science have been achieved. Yet, the population of individuals diagnosed with cancer is steadily increasing, and cancer patients virtually die due to metastasis. Therefore, it is important to develop a strategy to inhibit cancer metastasis with minimal toxicity to normal cells to enhance the quality of life of patients. In this regard, much research has focused on natural compounds with anticancer effects. Particularly, natural phytochemicals containing phenolic compounds are known to prevent cancer metastasis (1). The Korean prostrate spurge Euphorbia supina is reported to contain a number of biologically significant organic substances such as polyphenols and has been used as a folk medicine in Korea against a variety of inflammatory conditions. Therefore, we aimed to ascertain whether the polyphenols in Euphorbia supina (PES) have a suppresive effect on the invasion and metastasis of breast cancer cells.

Cancer metastasis involves several steps in which cellular responses between cancer cells and normal cells are coordinately involved. These include the entrance of cancer cells from the primary tumor into the vasculature, migration to distant organs, adhesion to endothelial cells lining the blood vessels, extravasation from the blood vessels and proliferation of secondary tumors. EMT is a process that converts an epithelial cell to a mesenchymal cell by promoting the loss of cell-cell adhesion, leading to the release of cells from the surrounding tissue, and finally enables cells to acquire the migratory capability to invade. Therefore, EMT can be regarded as an initial process of metastasis, and EMT occurring during tumor progression is considered to be the major mechanism that is responsible for the invasion and metastasis of cancer cells (22-24). Within the tumor microenvironment, tumors release several factors which can promote cancer metastasis; MMPs are involved in the proteolytic digestion of the ECM as well 

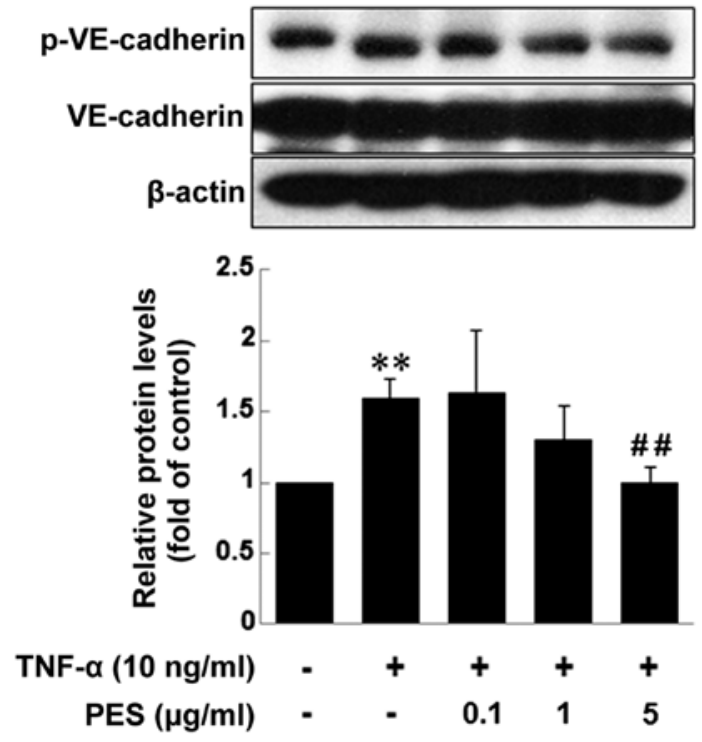

Figure 5. PES inhibits TNF- $\alpha$-mediated phosphorylation of VE-cadherin in ECs. EA.hy 926 cells were pretreated with PES $(0.1,1$ or $5 \mu \mathrm{g} / \mathrm{ml})$ for $1 \mathrm{~h}$, followed by incubation with TNF- $\alpha(10 \mathrm{ng} / \mathrm{ml})$ for $4 \mathrm{~h}$. VE-cadherin expression and phosphorylation of VE-cadherin (Y658) were determined by western blot analysis. Values are the means \pm SEM from three independent determinations. ${ }^{* * *} \mathrm{P}<0.01$, significant compared to the control; ${ }^{\# \#} \mathrm{P}<0.01$, significant compared to the TNF- $\alpha$-treated group.

as angiogenesis, which are major steps in cancer invasion. In addition, adhesion molecules such as ICAM-1 and VCAM-1 are involved in cell-cell and cell-ECM interactions and are mechanistically important for the extravasation of cancer cells during metastasis $(20,21)$. In particular, VCAM-1 is expressed preferentially or highly on breast cancer endothelium compared to normal endothelium $(25,26)$. Another important factor is endothelial cell membrane permeability regulated by transmembrane endothelial adherens junctions (AJs). In endothelial cells, AJs are largely composed of VE-cadherin. The phosphorylation, cleavage and internalization of VE-cadherin are thought to affect endothelial permeability (27). Thus, in the present study, we determined the effect of PES on the invasion and metastasis of highly metastatic breast cancer MDA-MB-231 cells.

As expected, PES significantly suppressed EMT by downregulating the mesenchymal markers, Snaill and $\mathrm{N}$-cadherin. In addition, PES significantly inhibited MMP-9 activity induced by TNF- $\alpha$ at $5 \mu \mathrm{g} / \mathrm{ml}$. Moreover, the release of LOX, an enzyme that crosslinks ECM proteins such as collagen and promotes breast cancer metastasis, was induced by TNF- $\alpha$, which was inhibited by PES treatment (mainly at $5 \mu \mathrm{g} / \mathrm{ml})$. Then, we determined the effect of PES on the expression of adhesion molecules and the phosphorylation of VE-cadherin. The results showed that PES effectively reduced TNF- $\alpha$-induced VCAM-1 but not ICAM expression in both the MDA-MB-231 cells and ECs, resulting in the decreased adhesion of MDA-MB-231 cells to ECs. Furthermore, PES suppressed LOX secretion by TNF- $\alpha$, suggesting that PES efficiently inhibited the invasion of MDA-MB-231 cells. Finally, when we assessed whether PES inhibits the invasion of MDA-MB-231 cells through ECs, the results showed that PES effectively inhibited MDA-MB-231 cell invasion through

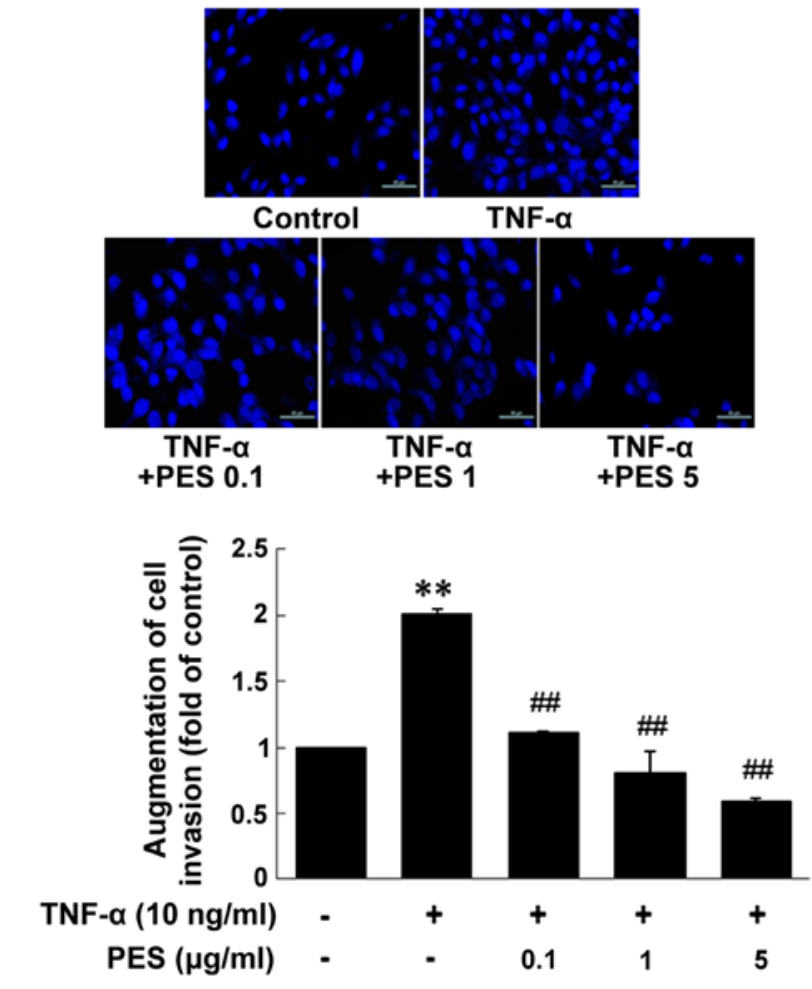

Figure 6. PES downregulates the invasion of MDA-MB-2341 cells induced by TNF- $\alpha$. MDA-MB-231 cells were pretreated with PES at $0.1,1$ or $5 \mu \mathrm{g} / \mathrm{ml}$ for $1 \mathrm{~h}$, and then stimulated with TNF- $\alpha(10 \mathrm{ng} / \mathrm{ml})$ for $6 \mathrm{~h}$ or not. After treatments, the cells were collected, applied to a Matrigel-coated insert well and then incubated overnight $(16 \mathrm{~h})$ at $37^{\circ} \mathrm{C}$. The non-invasive cells that remained on the upper side of the insert were removed, and the cells on the lower part of the insert membranes were stained with DAPI. The number of cells that invaded through the membrane was quantified by counting cells under a fluorescence microscope. Images from three randomly selected fields are presented. Values are the means \pm SEM from three independent determinations. ${ }^{* *} \mathrm{P}<0.01$ compared with the control group; ${ }^{\#} \mathrm{P}<0.01$ compared with the TNF- $\alpha$-treated group.

ECs at a very low concentration $(0.1 \mu \mathrm{g} / \mathrm{ml})$ where it showed no cytotoxicity on cancer cells and ECs.

The most abundant flavonoids in the diet, flavonols, exhibit numerous biological and pharmacological effects including anticancer-related properties (28), and quercetin and kaempferol derivatives are the major components of total polyphenols isolated and identified from Korean $E$. supine. Quercetin (3,5,7,3', '4'-pentahydroxyflavone) is an active component of flavonoids that abundantly exists in many fruits and vegetables, and dietary food sources. Quercetin exhibits various beneficial biological activities, such as anti-oxidant, anti-inflammatory, anti-atherosclerotic, and anti-tumorigenic activities (29-31). Quercetin was found to inhibit HL-60 leukemia cell proliferation in association with the inhibition of cytosolic protein kinase $\mathrm{C}$ and membrane tyrosine protein kinase in vitro (32). Furthermore, quercetin exerted anti-proliferative effects against glioma and breast cancer cells (33-35). It has been suggested that quercetin may be a potential antiinvasive compound in breast cancer cells $(36,37)$. In addition, kaempferol and its derivatives also exhibit a wide range of pharmacological activities including anti-oxidant, antiinflammatory, anticancer, anti-microbial, cardioprotective, neuroprotective, and anti-diabetic activities (38). Kaempferol induced apoptosis in HL60 leukemia cells which was accom- 
panied by significant DNA condensation and increased ATP levels. It also altered the expression of caspase-3 and apoptosis-inducing factor (39). The regular consumption of foods containing kaempferol has been positively correlated to a reduction in the risk for developing several disorders including cancer. In breast cancer, similar to the activity of quercetin, kaempferol exhibited inhibitory activity on the invasiveness and MMP-3 levels in MDA-MB-231 cells (37). Based on our results and these studies, PES containing quercetin and kaempferol may suppress the process of metastasis of highly metastatic breast cancer cells by regulating the adhesion of MDA-MB-231 cells to ECs by inhibiting VCAM-1 expression in ECs, and by reducing EC permeability and inhibiting EMT in MDA-MB-231 cells. Finally, PES may serve as a therapeutic agent against cancer metastasis with minimal cytotoxicity to normal cells.

\section{Acknowledgements}

The present study was supported by grants from the National R\&D Program for Cancer Control, the Ministry of Health and Welfare, Republic of Korea (no. 0820050).

\section{References}

1. Sliva D: Suppression of cancer invasiveness by dietary compounds. Mini Rev Med Chem 8: 677-688, 2008.

2. Tanaka R, Kurimoto M, Yoneda $M$ and Matsunaga S: $17 \beta, 21 \beta$-Epoxyhopan-3 $\beta$-ol and $\beta$-alnincanol from Euphorbia supina. Phytochemistry 29: 2253-2256, 1990.

3. An RB, Kwon JW, Kwon TO, Chung WT, Lee HS and Kim YC: Chemical constituents from the whole plants of Euphorbia supina Rafin. Korean J Pharmacognosy 38: 291-295, 2007.

4. Agata I, Hatano T, Nakaya Y, Sugaya T, Nishibe S, Yoshida T and Okuda T: Tannins and related polyphenols of euphorbiaceous plants. VIII. Eumaculin A and eusupinin A, and accompanying polyphenols from Euphorbia maculata L. and E. supina Rafin. Chem Pharm Bull (Tokyo) 39: 881-883, 1991.

5. Lee SH, Tanaka T, Nonaka G and Nishioka I: Tannins and related compounds. CV. Monomeric and dimeric hydrolyzable tannins having a dehydrohexahydroxydiphenoyl group, supinanin, euphorscopin, euphorhelin and jolkianin, from Euphorbia species. Chem Pharm Bull (Tokyo) 39: 630-638, 1991.

6. Fang Z, Zeng X, Zhang Y and Zhou G: Chemical constituents of spotted leaf euphorbia (Euphorbia supina) Zhongcaoyao 24: 230-233, 1993.

7. Erlund I: Review of the flavonoids quercetin, hesperetin, and naringenin. Dietary sources, bioactivities, bioavailability, and epidemiology. Nutr Res 24: 851-874, 2004.

8. Le Marchand L: Cancer preventive effects of flavonoids - a review. Biomed Pharmacother 56: 296-301, 2002.

9. Xu YC, Leung SW, Yeung DK, Hu LH, Chen GH, Che CM and Man RY: Structure-activity relationships of flavonoids for vascular relaxation in porcine coronary artery. Phytochemistry 68: $1179-1188,2007$.

10. Song Y, Jeong SW, Lee WS, Park S, Kim YH, Kim GS, Lee SJ, Jin JS, Kim CY, Lee JE, et al: Determination of polyphenol components of Korean prostrate spurge (Euphorbia supina) by using liquid chromatography-tandem mass spectrometry: Overall contribution to antioxidant activity. J Anal Methods Chem 2014: 418690, 2014.

11. Korean Breast Cancer Society: Korean breast cancer data of 1996. J Korean Surg Soc 55: 621-635, 1998.

12. Lu X and Kang Y: Hypoxia and hypoxia-inducible factors: Master regulators of metastasis. Clin Cancer Res 16: 5928-5935, 2010.

13. Kim HG, Kim GS, Park S, Lee JH, Seo ON, Lee SJ, Kim JH, Shim JH, Abd El-Aty AM, Jin JS, et al: Flavonoid profiling in three citrus varieties native to the Republic of Korea using liquid chromatography coupled with tandem mass spectrometry: Contribution to overall antioxidant activity. Biomed Chromatogr 26: 464-470, 2012.
14. Joo YN, Jin H, Eun SY, Park SW, Chang KC and Kim HJ: P2Y2R activation by nucleotides released from the highly metastatic breast cancer cell MDA-MB-231 contributes to pre-metastatic niche formation by mediating lysyl oxidase secretion, collagen crosslinking, and monocyte recruitment. Oncotarget 5: 9322-9334, 2014

15. Rucci N, Sanità P and Angelucci A: Roles of metalloproteases in metastatic niche. Curr Mol Med 11: 609-622, 2011.

16. Deryugina EI and Quigley JP: Matrix metalloproteinases and tumor metastasis. Cancer Metastasis Rev 25: 9-34, 2006.

17. Przybylowska K, Kluczna A, Zadrozny M, Krawczyk T, Kulig A, Rykala J, Kolacinska A, Morawiec Z, Drzewoski J and Blasiak J: Polymorphisms of the promoter regions of matrix metalloproteinases genes MMP-1 and MMP-9 in breast cancer. Breast Cancer Res Treat 95: 65-72, 2006.

18. Zoccoli A, Iuliani M, Pantano F, Imperatori M, Intagliata S, Vincenzi B, Marchetti P, Papapietro N, Denaro V, Tonini G, et al: Premetastatic niche: Ready for new therapeutic interventions? Expert Opin Ther Targets 16 (Suppl 2): S119-S129, 2012.

19. Mousa SA: Cell adhesion molecules: Potential therapeutic and diagnostic implications. Mol Biotechnol 38: 33-40, 2008.

20. Price JT and Thompson EW: Mechanisms of tumour invasion and metastasis: Emerging targets for therapy. Expert Opin Ther Targets 6: 217-233, 2002.

21. Balkwill $\mathrm{F}$ and Mantovani A: Inflammation and cancer: Back to Virchow? Lancet 357: 539-545, 2001.

22. Christofori G: New signals from the invasive front. Nature 441: 444-450, 2006.

23. Mitra A, Mishra L and Li S: EMT, CTCs and CSCs in tumor relapse and drug-resistance. Oncotarget 6: 10697-10711, 2015.

24. Yang $J$ and Weinberg RA: Epithelial-mesenchymal transition: At the crossroads of development and tumor metastasis. Dev Cell 14: 818-829, 2008.

25. Fox SB, Turner GD, Gatter KC and Harris AL: The increased expression of adhesion molecules ICAM-3, E- and P-selectins on breast cancer endothelium. J Pathol 177: 369-376, 1995.

26. Nguyen M, Corless CL, Kräling BM, Tran C, Atha T, Bischoff $\mathbf{J}$ and Barsky SH: Vascular expression of E-selectin is increased in estrogen-receptor-negative breast cancer: A role for tumor-cell-secreted interleukin-1 alpha. Am J Pathol 150: 1307-1314, 1997.

27. Dejana E, Orsenigo F and Lampugnani MG: The role of adherens junctions and VE-cadherin in the control of vascular permeability. J Cell Sci 121: 2115-2122, 2008.

28. Middleton E Jr, Kandaswami C and Theoharides TC: The effects of plant flavonoids on mammalian cells: Implications for inflammation, heart disease, and cancer. Pharmacol Rev 52: 673-751, 2000.

29. Naderi GA, Asgary S, Sarraf-Zadegan N and Shirvany H: Anti-oxidant effect of flavonoids on the susceptibility of LDL oxidation. Mol Cell Biochem 246: 193-196, 2003.

30. Mamani-Matsuda M, Kauss T, Al-Kharrat A, Rambert J, Fawaz F, Thiolat D, Moynet D, Coves S, Malvy D and Mossalayi MD: Therapeutic and preventive properties of quercetin in experimental arthritis correlate with decreased macrophage inflammatory mediators. Biochem Pharmacol 72: 1304-1310, 2006.

31. Lotito SB and Frei B: Dietary flavonoids attenuate tumor necrosis factor alpha-induced adhesion molecule expression in human aortic endothelial cells. Structure-function relationships and activity after first pass metabolism. J Biol Chem 281: 37102-37110, 2006.

32. Kang TB and Liang NC: Studies on the inhibitory effects of quercetin on the growth of HL-60 leukemia cells. Biochem Pharmacol 54: 1013-1018, 1997.

33. Braganhol E, Zamin LL, Canedo AD, Horn F, Tamajusuku AS, Wink MR, Salbego C and Battastini AM: Antiproliferative effect of quercetin in the human U138MG glioma cell line. Anticancer Drugs 17: 663-671, 2006.

34. Indap MA, Radhika S, Motiwale L and Rao KVK: Quercetin: Antitumor activity and pharmacological manipulations for increased therapeutic gains. Indian J Pharm Sci 68: 465-469, 2006.

35. Choi EJ, Bae SM and Ahn WS: Antiproliferative effects of quercetin through cell cycle arrest and apoptosis in human breast cancer MDA-MB-453 cells. Arch Pharm Res 31: 1281-1285, 2008. 
36. Lin CW, Hou WC, Shen SC, Juan SH, Ko CH, Wang LM and Chen YC: Quercetin inhibition of tumor invasion via suppressing PKC delta/ERK/AP-1-dependent matrix metalloproteinase-9 activation in breast carcinoma cells. Carcinogenesis 29: 1807-1815, 2008.

37. Phromnoi K, Yodkeeree S, Anuchapreeda S and Limtrakul P Inhibition of MMP-3 activity and invasion of the MDA-MB-231 human invasive breast carcinoma cell line by bioflavonoids. Acta Pharmacol Sin 30: 1169-1176, 2009.
38. Calderón-Montaño JM, Burgos-Morón E, Pérez-Guerrero C and López-Lázaro M: A review on the dietary flavonoid kaempferol. Mini Rev Med Chem 11: 298-344, 2011.

39. Leung HW, Lin CJ, Hour MJ, Yang WH, Wang MY and Lee HZ: Kaempferol induces apoptosis in human lung non-small carcinoma cells accompanied by an induction of antioxidant enzymes. Food Chem Toxicol 45: 2005-2013, 2007. 